\title{
Nietzsche's Idea of the 'Will to Power' and its Implications for Globalization and African Cultural Values
}

\author{
Bruno Yammeluan Ikuli (Ph.D $)^{1} \quad$ Anthony C. Ojimba $(\mathrm{PhD})^{2^{*}}$ \\ 1.Institute of Foundation Studies, Federal University, Otuoke, Bayalsa State, Nigeria \\ 2.Department of Philosophy, University of Nigeria, Nsukka, Enugu State, Nigeria
}

\begin{abstract}
The Will to Power represents Nietzsche's critical, analytic, deconstructive and interpretive tool, while globalization designate a doctrinal process of advancement and increase in interaction among countries, facilitated by progressive technological development, communication, knowledge and skills, as well as interaction of cultural values, systems and practices. Globalization, as a doctrine, has brought with it both negative and positive values, and has invariably posed serious challenges to Africa in relation to the erosion of her cultural values, especially, her most cherished cultural values. This challenge becomes very significant, especially with regards to the fact that these values are Western oriented and, in most cases, not congenial with the African cultural milieu. The implication of this phenomenon is the increase in the rate of cultural adulteration of Africa by the West and her epistemic dependency on the Western world. In line with the above, the problem this paper tackles is how to harness the positive values of globalization while, at the same time, checkmating its ugly effects on African cultural values. The main purpose of the paper is to provide a way of tackling the challenges posed by globalization, on African values system, while strategically mapping out a way of harnessing its positive principles. Using the method of historical hermeneutics and textual analysis/exposition, this paper argues that Nietzsche's principle of the Will to Power, as a deconstructive and analytic principle, constitutes a sifting tool towards harnessing the positive values of globalization on African culture while, at the same time, checkmating its ugly menace.
\end{abstract}

Keywords: globalization, will to power, superman, nihilism, perspectivism, democracy, politics of subjectivity, revaluation of values, cultural adulteration, critical literacy and epistemic dependency.

DOI: $10.7176 /$ RHSS/9-20-08

Publication date:October $31^{\text {st }} 2019$

\section{Introduction}

It is a truism that no country can survive entirely on its own, without the help of another country. This implies that no country can live in isolation. The Greek philosopher, Aristotle, had this in mind when he said that "man is a political (social) animal" and that any man, who can survive entirely on his own, without the help of another is either a god or a beast (Aristotle, 1991). The social nature of man, as Aristotle emphasized, lends credence to the idea that the proper existence of one country requires the support of another. That is to say, societies need the help of one another in order to have all needed of a good society to function.

The African (Igbo) popular adage of Igwebuike (the community is our strength) reinforces the Aristotelian social nature of man and society (Oluwagbemi-Jacob and Ojimba, p.76). This implies that every man and, in this case, society, requires the assistance of another. Similarly, for one country to exist and function properly as a country, it requires the assistance of another country. This assistance can come in form of borrowing ideas, values, skills, technology or even language (Ojimba, Bruno, and Haaga, 2015). This borrowing or interaction affects or influences a country's culture both positively and negatively. African societies and cultures are not exempted from these influences. This reinforces the concept of globalization, which is "a process of advancement and increase in interaction among countries and peoples, facilitated by progressive technological development, communication, knowledge and skills, as well as interaction of cultural values, systems and practices" (Nsibambi, 2001).

African interaction and increased communication with the rest of the world, which is driven by the spirit of globalization, has influenced her culture both negatively and positively (Oluwagbemi-Jacob and Ojimba, p.76). In fact, some African scholars have argued that the negative influences of globalization on African culture far-more outweigh the positive influences. Others went further to argue that African cultures are so weak to compete with the rest of other cultures and are bound to loose in the battle or competitive cultural struggle with the rest of the world. This situation is lamentable, especially with regards to the fact that African leaders exhibit a nonchalant attitude towards a constructive and critical regulation of the inflows of western ideas and values. However, since African leaders are less concerned in critically and pragmatically regulating the inflows of western ideas into Africa, and since most of the values in existence, today, in African soil are western-oriented, do they not constitute a serious threat to the survival of African culture? This question becomes highly significant, especially with regards to the fact that most of these western values are not congenial with African cultural milieu. The question, once again, is: do these western values that saturate African culture, today, not pose a serious threat to the survival of our most cherished cultural ideals? This important question represents the fulcrum on which this paper rotates. This goes a long way in establishing the fact that African leaders and society require a tool that will enable them 
to critically, courageously, constructively and pragmatically regulate and control the ugly influences of western values on African culture, brought about by the spirit of globalization. It is against this backdrop that the paper argues that Nietzsche's idea of the will to power represents this constructive, critical and analytic tool, to enable African society harness the positive values of globalization, while pragmatically and constructively checkmating its ugly effects on African culture (Oluwagbemi-Jacob and Ojimba, p.77). However, before delving into the main theme of our reflection, a brief conceptual clarification will be appropriate.

\section{Conceptualizing Will to Power, Globalization, African Culture and African Values}

According to Nietzsche (1967), "the Will to Power represents the most intimate essence of being - the fundamental explanatory principles of all things" (p.148)In his estimation, it is a flexible, deconstructive and analytic tool, which is deeply rooted in the notion of becoming, endless interpretation and creative possibilities. "Globalization," on the other hand, as conceived by Igwe (2005) designates "a doctrinal process of advancement and increase, in interaction, among countries and peoples, facilitated by progressive technological development, communication, knowledge and skills, as well as interaction of cultural values, systems and practices."

Nietzsche (1967) conceives values as "conditions of preservations and enhancements for complex forms of relative life-duration within the flux of becoming" (p. 380). Similarly, value can be viewed as the principle and standards of behaviour. In line with this, African values will then mean an African standard way of doing things or the conditions of preservation and enhancement of African way of life, reality or cherished ideals.

The understanding of culture is necessary if we wish to understand the full import of this paper. Hofstede (1980) and Adler (1983) see culture as "the collective programming of the mind, which distinguishes the members of one human group from another - the interactive aggregate of common characteristics that influence a human group's response to its environment." Similarly, Schein (2003) defined it as "a set of basic solutions - shared solutions to universal problems of external adaptation (how to survive) and internal integration (how to stay together) - which have evolved over time and are handed down from one generation to the next." Ultimately, it represents the customs, ideas, and social behaviour of a people. Thus, it is the totality of the way of life of a group of people that has been developed, shaped and practiced over the years (Kwame, n.d). The development of these cultural norms and practices are modeled by the environment and needs of the people.

The culture of a people can be negatively or positively influenced by another people, due to interaction and increased communication with other foreign cultures. This is the fruit of globalization and the case in today's African societies, where the inflows of Western ideas are not properly regulated. Most importantly, these ideas and values are Western-based and are not congenial with African cultural milieu. Consequently, they pose serious threats to the survival of African culture, as well as its continual existence. This makes it highly imperative for Africa to regulate the speed of globalization - the inflows of western values. But before going fully into this, a brief historical sketch of globalization and the African experience will be apposite.

\section{A Brief Historical Sketch of Globalization and the African Experience}

The concept of globalization is not a novel idea. Before now, there have been various stages of globalization. These include $1870-1914,1945$ - 1980 and from 1980 till the present stage (Ajayi, 2003).This makes the concept dependent on the definition each particular scholar gives it. Basically, with regards to Africa, international contacts and exchanges are not new (Kwame, n.d). Africa had been in contact with other parts of the world and also had significant interactions within it.

Interaction with the outside world, particularly Europe and America, started way back in the 15 th century. During this period, the Western merchants bought from Africa, the most valuable resources from African slave traders. These were African able bodied men, including women and children. This started through trade, especially, the trans-Atlantic slave trade. This has significantly altered the course of Africa historically, culturally, politically and economically (Kwame, n.d). "Compared with the devastating experience of the trans-Atlantic slave trade, which considerably depopulated the Africans, colonialism [which is the second stage of globalization when, Europeans at a conference, in Berlin, in 1884, divided up Africa among themselves and instituted direct control and rule over African countries (Kwame, n.d)] represents a higher and more disastrous form of slavery (Obioha, 2010 p. 1). This is why Ekwuru (1999) refers to it as "the 'deculturisation' and 'depersonalization' of a people within their own land." The dehumanizing effects of colonialism continue to have a "horribly debilitating experience, which has continued to surface as a terrible nightmare of inferiority on the cultural psyche of the colonized" (Obioha, 2010, p. 3). In line with this, some scholars view it as "a system of political, economic and cultural domination, forcibly imposed by a technologically advanced foreign minority on the on indigenous majority" (Geller, 1995).

The next stage of African interaction with the world, particularly Europe, was during the era of independence from colonial rule. Within the last decade of the 20th century into the $21^{\text {st }}$ century, Africa's linkage with other parts of the world entered a new phase commonly termed as globalization. Thus, despite that the term, 'globalization,' may be new, its substance and ideals are not new to Africa and the world as a whole. 
The speed of globalization in the world has led some scholars to propound the idea of a global culture, which is practically impossible. However, because of time and space, we will not like to delve deeply into the argument concerning the possibility of the emergence of a global culture. However, since most of the Western values that come into Africa, as a result of globalization, are not congenial with the African cultural milieu, do they not constitute a serious threat to the erosion of African cultural values? This is the main focus of this paper. However, before delving fully into this reflection, it will be apposite to put Nietzsche's idea of the Will to Power in perspective, which is a deconstructive and analytic tool, and which this paper recommends as a solution to the problem posed by globalization with regards to the extinction of African cultural values.

\section{Nietzsche's Idea of the Will to Power}

The will to power represents Nietzsche's analytic, deconstructive and critical tool (Oluwagbemi-Jacob and Ojimba, p.76). He explicitly underlines and affirms, in various ways, that everything that exists is, at bottom and, in its very totality, will to power. This means that "the essence of the world is will to power" (Nietzsche, 1967, p. 148). Life also, for Nietzsche, is will to power. The most intimate (fundamental) essence of being is, also, will to power. Thus, there are no ultimate things, in themselves, but only formations of the will to power. That is to say that, the will to power, for Nietzsche, is the most fundamental explanatory principle of reality.

It is important to discard, from the beginning, as a gross misconception, any interpretation of the will to power that is solely psychological or anthropological. So construed, it would simply be synonymous with hunger for power, and it would be a matter of each individual desiring to dominate the others and to subjugate things (Oluwagbemi-Jacob and Ojimba, p.76). It can easily be shown that such a will would, in reality, be impotent, constantly suffering from an inadequacy and undergoing a perpetual nostalgia.

Nietzsche characterizes the will to power as deeply rooted in the notion of becoming rather than a substance or a substrate. For him, "it is the force, behind all forms" (Lingis, 1985, p.38). It is not just power or force, but will to power: always will for more power. For Nietzsche, it is neither structure, "telos," nor meaning, but continual "sublation" of all "telos," transgression of all ends, production of all concordant and contradictory meanings, interpretations and valuations. It is the chaos, the primal fund of the unformed - not matter, but force beneath the cosmos, which precedes the forms and makes them possible, as well as transitory. He maintains that "the will to power is an abyss: the groundless chaos beneath all the grounds and all the foundations, which leaves the whole order of essences groundless" (Lingis, 1985, p.38).

As explained above, the will to power represents Nietzsche's deconstructive and analytic tool, as well as his unique style of questioning. In his estimation, it a flexible and dynamic tool, which is deeply rooted in the notion of becoming, endless interpretation and creative possibilities. For him, it is a critical and non-dogmatic principle, which does not accept any idea without challenging it. It designates the ability to challenge and the courage to critically question the basic foundations of thoughts, beliefs, ideas and assumptions, which are uncritically and dogmatically accepted as true, absolute, objective, unconditional and unquestionable. He conceives the will to power as a tool of liberation and a new way of thinking beyond the hegemony of Western authority, Western epistemology and Western metaphysics. This informs the reason why he conceives his entire philosophy as a counter-movement to Western traditional way of thinking and authority as represented by Platonic Western philosophy and authority. This is particularly, because, western culture, according to Nietzsche, posits itself as the absolute culture and final authority and conceives every other culture or reality as a sub-standard. For him, Western civilization advocates for a universal culture which, for him, is practically impossible and amounts to cultural domination of the West over other cultures. Based on this, Nietzsche advocates cultural perspectivism or pluralism, which is a cultural principle that accommodates every other way of thinking and accords respects and recognition to every other culture. What Nietzsche attacks, here, is the influence and hegemony of one culture over another, in form of globalization and western civilization. This can easily be noticed, for example, in Africa, where there is a blind adoption of Western culture, in the name of Western civilization, which is posing a serious threat to the survival of African cultural values. This is because, most of these western values, trooping into Africa, in the name of globalization and western civilization, are not congenial with African cultural milieu. Consequently, they constitute a threat to the continual existence of African culture, as most of our cherished cultural ideals have gone into perpetual extinction and permanent oblivion. This idea or reason was what informed Nietzsche's critique on western values and authority because of their hidden and deceptive attempt to subjugate, dominate and relegate other cultures to the background. He, therefore, embarked on his philosophical movement of the Will to Power, which is a dynamic, analytic, critical and deconstructive principle, that does not accept any idea without, first of all, challenging, scrutinizing or criticizing it. Consequently, African culture can borrow a leaf from Nietzsche's deconstructive tool of the will to power to scrutinize and regulate the inflows of Western culture in form of globalization, which is constituting a serious threat to the survival and continual existence of our most cherished African cultural values. 


\section{Globalization, African Cultural Values and the Will to Power}

As pointed out above, globalization designates "a process of advancement and increase in interaction among countries and peoples, facilitated by progressive technological development, communication, knowledge and skills, as well as interaction of cultural values, systems and practices" (Nsibambi, 2001). Globalization, no doubt, has made tremendous progress in improving the quality of lives of people around the world. However, the explosive consequences they portend, especially, with regards to the erosion of African cultural and democratic values, are paradoxical.

Some scholars are of the view that the negative effects of globalization, for instance, far more outweigh the positive effects. Thus, it was their opinion that Africa has been the worst hit for the negative impact of globalization. This implies that "globalization is more of a curse than a blessing." (Oseni, n.d, p. 4). Globalization has been the engine room for the propagation of Western culture on African soil. The greatest venture, upon which the negative impact of globalization rests on Africa, is on her cultural heritage, egalitarian and democratic principles. The forceful integration of Africa into globalization through slavery and colonialism has led to the problem of personal identity and cultural dilemma for the African (Oseni, n.d, p. 5). In line with this, Maduagwu opines that "ever since their experience with colonialism, African countries have been unable to independently articulate or chart their own history, politics, culture and identity (cited in Oseni, n.d. p. 5). The apparent display of Western cultures and values in Africa, by Africans, is a testimony to the erosion of African cultures and values. The traditional African cultural values are fast going into extinction due to the negative impact of globalization. The African values, democratic principles and economies are fast degenerating because of "their replacement with the cultural values of the more technologically and economically advanced Western countries" (Oseni, n.d., p. 5-6).

According to Ogunjimi and Allah, "the peculiar Nigerian cultural values, like languages, are being eroded by the pop culture brought about by globalization. Greeting norms, cuisine appearances, custom, occupations, religion and cultural components are giving way to acculturation - the suppression and subjugation of African culture - a tragic phenomenon that is fast destroying the original cultural complexion of, not only the budding generation, but even the adults" (cited in Ugbam, Chukwu \& Ogbo, 2014, p. 66). Similarly, our educational system is not left out of the ugly effects of globalization. In this connection, Odimegwu (2005) was of the view that "at the various levels of education, particularly the secondary and tertiary institutions, teachers and pupils, lecturers and students engage in various forms of corrupt practices, which negate the communal spirit and are detrimental to the goals, which education ought to achieve. For him, "such evils as admission racketeering, exam malpractice, sexual harassment of students by lecturers and vice-versa, sale of marks, lack of sense of duty, indifference to social responsibility and public property, indecent dressing and the general decay of the moral sense, all culminating in abysmally low performance of students, are now common features of most secondary and tertiary educational institutions" (cited in Ugbam et al., 2014, p. 66).

Some writers see African cultures as being too weak, when compared with Western culture and consequently bound to loose in battle against Western culture. It is line with this idea that Oni (2005) opines that "the situation in Africa, today, is so pathetic as a result of the gradual admittance of western culture, at the detriment of our own culture. Africa has consequently changed from a land of culture and nature, and of tradition and rural setting, where the cockcrow signals the dawn of a new day" (cited in Ugbam et al., 2014, p. 66). Similarly, Nicolaides (2012), in accessing the level of cultural adulteration and decadence among the South African youths, has this to say: "the younger generation of teenagers in south Africa have, for the most part, abandoned their African culture and language, and often religion and try to be hip-ups by imitating their mainly American rap artist role models, who, for most part, display an acute lack of values and act immorally on television shows, and who promote promiscuous behaviour, especially, in the lyrics of the music they write" ( cited in Ugbam et al., 2014, p. 66). The disappointment, here, is that the youths, who are supposed to be the carriers and transmitters of African culture, from one generation to another, are the ones working towards its erosion as a result of the influence of Western culture on them. This situation is highly deplorable, especially with regards to the fact that the youths are the vital segment of the society, who are supposed to be instrumentals in the promotion of African cultural values. Regrettably, the mentality and thought patterns of the African teenagers have been conditioned and patterned by their indiscriminate exposures and influence by Western cultures. This culture now serves as a standard within which their entire lifestyles are conditioned. The implication of this ugly phenomenon is the increase in the rate of cultural adulteration of Africa by the West and the continuation of her epistemic dependency on them. This is because, one who structures the thought pattern of another and his entire lifestyle also conditions his/her perception of reality. To this extent, one can conclude that the African epistemology (thought patterns) and their metaphysics (perception of reality) have been drastically influenced by the Western culture. This influence is glaring, especially, with the African youths, and this is the fall out of globalization.

Globalization has further instituted a radical shift from the African value of communalism to that of extreme individualism. Africans are now cultivating the materialistic and individualistic habits previously associated with Western culture. The culture of individualism is fast eroding the values and ideas of the extended family-system, which Africans are known for. Excessive materialism has, for instance, changed the religious character of the 
traditional African Igbo society of Nigeria (Obioha, 2010). In a similar manner, "most women in Africa, today, dress half-naked while their male counterparts braid their hairs, put on earrings and nose-rings and wear torn clothes or rags all in the name of fashion. Generally, globalization has brought about the decline of the traditional world, the undoing of the old cultural set-up, and the rapid erosion of old values" (Ohioha, 2010, p. 4). This is a clear indication that the African culture is speedily running into perpetual extinction.

Nietzsche's idea of the Will to Power can serve as an antidote towards cushioning the ugly effects of globalization on African cultural values. His concept of the Will to Power represents a deconstructive, interpretive, critical and analytic tool, which is deeply rooted in creative possibilities, endless questioning and critical interpretation.It is a critical and non-dogmatic tool, which does not accept any principle, without challenging it. It designates the ability to challenge and the courage to critically question the basic foundations of thoughts, beliefs, ideas and assumptions, which are uncritically and dogmatically accepted as true, absolute, objective, unconditional and unquestionable. It designates a unique style of questioning that unravels or critically unmasks the hidden agendum behind any doctrine or idea. This reminds one of Socratic style of questioning. It instills courage, critical literacy and critical-mindedness in the minds of its adherents and enables them to challenge any idea or authority. It conceives nothing as absolute, but represents everything as interpretation of the human mind. This principle can instill the sense of criticality and critical-mindedness needed in Africa to checkmate the ugly menace and influence of globalization. It can instill critical literacy in the mentality of our Africa leaders to curtail and control the inflow of Wester ideas, which are responsible for the basterdization of African culture. This is not to say that globalization has not brought with it any positive thing, but only to constructively and critically accept any foreign ideal. Although Nietzsche is not an African, but a German, but his principle of the Will to Power, which is vibrant and dynamic principle, when properly and rightly applied, canhelp the African society in constructively and critically checking the ugly influence of globalization on African culture.

Nietzsche was critical of traditional philosophy, as represented in the Platonic philosophy, because of its tyrannical and hegemonic tendencies. This is because, for him, the Platonic Christian authority cultivated a method of thinking (epistemology), a notion of "good" (morality) and a method of reality (metaphysics) that suppressed other thought systems. It tried to cultivate the emergence of a universal culture which, for Nietzsche, was practically impossible. This reason informed Nietzsche's attack on Platonic philosophy. This same situation is applicable in today's Africa. Globalization is an attempt to lure African culture into a universal cultural pool, in which it will be weak to compete with other stronger and higher cultures. The consequences of this will be the erosion of African culture and over-dependency on Western culture. Nietzsche's principle of the Will to Power can, therefore, act as a salvaging ground, for Africa, in the sense that it can instill the sense of constructive thinking and critical borrowing of Western ideas while, at the same time, preserving her most cherished cultural values and ideals. This attitude will culminate into African cultural elevation, instead of cultural extinction. This can further be explained in the theory of the Superman, which is the highest expression of the will to power.

\section{The Superman, Globalization and the African Culture}

The theory of the superman, as propounded by Friedrich Nietzsche, represents another way of curbing the ugly menace of globalization and its negative effects on African culture. It is not a personality that would result from the practical application of Nietzsche's philosophy to life. For him, it is the highest embodiment and manifestation of the Will to Power. It designates a new way of thinking beyond the hegemony and tyranny of Western civilization. It is a deconstructive and critical way of harnessing the positive values of globalization, while at the same time, checkmating its ugly effects on African culture (Ojimba and Bruno, 2019).

Nietzsche's concept of the superman was fully discussed in his most favorite book: Thus Spoke Zarathustra, which he described as "a book for all and none" (Nietzsche, 2006, p.iii). The superman is the theme of the first speech in Zarathustra's prologue, which he presented to the crowd, who gathered to hear him (Nietzsche, 2006, p.5).The theory of the superman "would be a myth, which possessed truth, in so far as it enables the higher type of man to develop his full potentials" (Chukwuelobe, 2012, p.45). It is the affirmation of life - saying yes to life, and not no to life's challenges. The superman represents the affirmation of one's full potentialities, freedom and creativity. It designates the essence of humanity; that is, the highest principle or development of humanity. It is a statement of freedom and liberation of man from the tyranny of Western cultural absolutism. It is important to note, as earlier pointed out, that Nietzsche's superman is an ideal postulation and not a personality that would result from the practical application of his philosophy to life.

Nietzsche's superman does not negate life but affirms it. It represents the capability to transform the world and uphold one's freedom, potentiality and creativity (Ojimba and Bruno, 2019).. However, the superman can only accomplish this through the forceful rejection of cultural subjugation and domination of his culture by a foreign culture. The superman is "the noble type of man, who creates his own values and who combines the beauty and strength of the animal, with intellectual powers, which will enable him to resist the domination and subjugation of his culture by foreign ideals" (Roubiczek, 1966, p.32). The superman is "the master of the earth" (Nietzsche, 2006, p.3), fulfilling the mission of the earth and giving meaning to history. In other words, he is a law giver, a law 
interpreter and one who directs the affairs of the earth - a man-god.

The superman is also an embodiment of life-affirmation through the acceptance of the totality of life and the suffering entailed in living. Nietzsche posits the superman as a being, whose distance from conventional humanity is greater than the distance between man and beast. Thus, "the superman rejects all conventional human practices and values and invents his own value, which in relation to the existing values, will be new ones" (Nietzsche, 1966, p.135). He represents "the essence of humanity" (Heidegger, 1977, p.98) - one who breaks the tradition of cultural and epistemic dependency on foreign values. The superman is not necessarily a perfect physical specimen, a strong, healthy, athletic man, but an expression of free spiritedness. A sublime man could have the highest value, even if he is terribly delicate and fragile, because, an abundance of great and rare things have been bred and preserved together in him.

When Nietzsche speaks of a 'higher type' that will become the 'higher aristocracy of the future', he is talking about the superman. This is the same group that is depicted as ' "the future masters of the earth,' the 'legislators of the future,' the 'free spirits of the future,' the coming 'master race,' the coming 'ruling caste'- all of which must mean the same as his 'higher sovereign species,' his 'stronger race,' or 'stronger type"'(Fortich, 2010, p.75-80). Thus, the superman represents an expression of a strong will and free spiritedness - an affirmation of one's full potentialities, freedom, creativity, natural drives, strength of the spirit and energy. It is a man, who has a strong will to liberate himself from the dictatorship of foreign culture which, in Nietzsche's estimation, has enfeebled man, denied his freedom and creativity and made him incapable of facing his life's challenges. This enfeeblement of man by western civilization informed why Nietzsche declares the death of God which, for him, is the death of Western ideals, and why he is critical of Western civilization.

African societies need supermen as leaders, who will liberate the African mind from the epistemic dependency of the Western world. Nietzsche's theory of the superman represents an antidote for decolonizing the mind of an average African. It designates a window of epistemic freedom, cultural independence and ontological elevation of the African personality. This theory will enable African leaders affirm our cultural identity, ontological freedom and the existence of the African man. It will facilitate a critical, pragmatic and deconstructive applications of the values of western civilization, while intelligently curbing its negative values on African culture. In addition, it will enable African leaders put a final stop to Western epistemic dependency and cultural hegemony, as well as open a new window of thinking for the African leaders. This will help the Africans affirm their existence and position in the speedily globalizing world, while preserving our most cherished African cultural values and ideals. This will also enable our leaders to understand that our uniqueness is our identity and beauty.

This is not to say that Africans should be backward in their thinking, but only to say that African leaders should critically, constructively, pragmatically and intelligently adopt western values that will complement our African identity, instead of ignorantly or blindly keying into the spirit of globalization that will eventually constitute a foundation for the erosion and perpetual extinction of African culture. Nietzsche's theory of the superman, which he describes as the highest manifestation of the will to power, thus represents this critical, intelligent, constructive and pragmatic way of thinking beyond the hegemony of Western tradition and civilization, as it will culminate in harnessing African potentiality, creativity, uniqueness and finally, the affirmation of African cultural freedom, existence and place in the comity of nations. Nietzsche's theory of the superman is liked to his idea of 'perspectivism,' which emphasizes endless interpretations.

\section{7. 'Perspectivism,' Globalization, African Values and the will to Power}

Nietzsche's will to power, as has been pointed out above, is a deconstructive as well as an interpretive principle. Nietzsche is of the view that the will to power is the name for the perspective from which everything is interpreted and deconstructed as a process of interpretation that constantly attempts to overpower other earlier interpretations. The deconstructive nature of the will to power manifests itself in this interpretive process. It situates itself among interpretations that are competing with one other and, by doing so, it accounts for a plurality of interpretations. For Nietzsche, therefore, it does not divest the world "of its rich ambiguity" (Nietzsche, 2001, p.237) as did dogmatic Western civilization. This implies that the will to power opens up an infinite plurality of interpretations: it is the principle of cultural plurality, which is against the cultural monism or absolutism posited by globalization and Western civilization. Particularly, this explains why Nietzsche is of the view that "facts are precisely what there are not, only interpretations" (Nietzsche, 1967, p.267).For him, there is no real world, other than this one that exists in a process of interpretations trying to overpower one other. This is particularly intended to dismantle the dogmatic Western civilization during his time, which he analyzed in terms of decadence and madness. Nietzsche was trying to launch a coherent attack on the values of civilization, which he believes have enfeebled man, 'hegemonized' and made him incapable of affirming his uniqueness and identity - to express his full natural drives or potentiality, which is his will to power. Ultimately, Nietzsche's approach, here, is very deconstructive of the Western authority during his time. He intends to represent the Western values and ideals only as a perspective, which cannot posit itself as the absolute principle, or absolute culture, which every other culture should emulate. His whole idea, here, is to dethrone the Western authority from their cultural pre-eminence assigned to them by 
the doctrine of globalization and Western civilization.

Nietzsche is of the view that any culture that exist, in reality, is an interpretation, which is moved by the will to power. This means that, in Nietzsche's view, the will to power is another name for the interpretive and deconstructive process. For him, as there is no interpreter (culture), who could back out of this process of interpretation (the subject is also a figure of the will to power and, as such, an interpretation), so there is no subject matter of the interpreting process, except that which is, itself, already an earlier interpretation. This implies that, for him, reality is made up of endless interpretations and re-interpretations. His process of deconstruction takes its root from this principle of interpretation and re-interpretation. This implies that in Nietzsche's estimation, every culture is just a perspective or an interpretation, which should not claim superiority or domination of other cultures, in form of globalization or civilization. Therefore, since every culture is just a perspective or an interpretation, the idea of one culture positing itself as a universal culture (which is what globalization is indirectly enforcing) is, for Nietzsche, a cultural genocide and misnomer. Thus, by defending the idea of 'perspectivism' and interpretation, Nietzsche defends cultural pluralism and imposes the definition of culture as a text, which is just an interpretation, and which should not see itself as the only existing culture - the idea of cultural monism. This is what globalization has intended to accomplish. In African societies, today, African youths now emulate Western culture, which they see as one and only superior culture. Our most cherished cultural ideals are fast going into extinction. For instance, due to uncontrolled inflows of Western technology, which accelerates the speed of globalization, like the internet and other electronic applications, pornography has become a thing of the day for African youths.

In today's African society, pornography is made available to the average African youth just at the click of a computer mouse. For young people growing up in this era of ever-new and accessible technology, which is a twin sister of globalization, it is almost impossible to avoid exposure to pornography. Consumption, particularly for young men, has become normalized. The ways young people understand and experience gender and sex are being influenced by what they - or their partners or peers - observe in porn (Crabbe \& Corlett, 2011, p. 12).Technology, as the twin sister of globalization, has assisted in this movement of porn to the mainstream by providing ever cheaper and easier ways of manufacturing sexually explicit material and by providing platforms through which to deliver this material. It enables easy access to the multitude of free pornographic images available online. Significantly, this can be done anonymously (Crabbe \& Corlett, 2011, p. 12).

Access to explicit imagery is only part of the story of the mainstreaming of pornography. The pornography industry has had an incredible influence on African culture and this is made possible through the internet technology, which comes with the spirit of globalization. A porn aesthetic has thus pervaded African culture and this can be found in the areas of fashion, music, entertainment and behaviour. This is evident in the billboards, music videos and designer stores that shape the desires and imaginations of a younger African mind (Crabbe \& Corlett, 2011). It is not just that African culture has become more sexualized; but the imagery of the pornographic erotic has shaped the sexualisation of African culture. There are certain porn insignia that are now commonplace among African youth within the African culture, such as the use of porn labels and messages on clothing. The pervasiveness of this porn signature provides a kind of legitimacy to porn itself. This ugly situation, which is made possible through the internet technology, which is an outcome of globalization is lamentable. In the traditional African context, youths, especially young girls, avoided nude images and pre-marital sex experience for fear of social punishment usually meted out to those who lose their virginity before marriage. Today's situation indicates a sharp deviation from what was obtainable in the traditional African setting. Globalization, through its accelerator, which is technology, has made it easier for the young youths to have free access to erotic and sexual images, especially through the internet technology. This is, because, "the internet is a widely accessible, anonymous and unregulated marketplace - people can access the sorts of material that, in the past, they may have had to work harder andbe more discrete to consume" (Crabbe \& Corlett, 2011, p. 12). This constitutes a serious threat to the erosion of African cultural values.

Nietzsche's idea of perspectivism or endless interpretation, which is driven by his principle of the will to power and which is a dynamic, critical and deconstructive principle, can help African society launch a coherent and organized attacks on this ugly influence of globalization on African culture. It will instill critical literacy in African mentality that will enable it critically and constructively checkmate the inflows of Western values and their negative effects on our most cherished African cultural values. Nietzsche's perspectivism, which is another highest manifestation of the will to power, will enable the African leaders effectively deconstructs the ugly menace of Western ideals, which they will come to see only as a cultural perspective or a cultural interpretation in a comity of cultural interpretations of perspectives, in which every culture affirms its uniqueness, identity and existence and not succumbing to the hegemony of other cultures, in the deceptive form of globalization or western civilization. Thus, what Nietzsche intends to accomplish with his idea of cultural perspectivism is to defend the idea of cultural pluralism as against cultural monism or absolutism. This will enable African culture have a say in the comity of cultures and come to the realization that our cultural uniqueness is our identity and beauty. 


\section{Globalization, African Democracy, Nihilism and the Politics of Subjectivity}

Africa's increased interaction and communication with the rest of the world, brought about by the spirit of globalization, has also affected her traditional democracy. Democracy thrives on the principle of liberty and the belief that all men are created equal. This reflects the true picture of African egalitarian society. In a traditional African society, individuals were accorded deserved respects on the bases of humanity and with the idea that all men are created equal by God. However, the spirit of globalization has inverted and adulterated the true nature of African democracy. Our most cherished African democratic principles have been turned upside down and inside out. The ugly effects of globalization have negatively opened the eyes of African race just as Adam's eyes were negatively opened after eating the forbidden fruit. In today's African society, unlike before, people are yet to be treated equally, as they suffer enormously on the bases of rank and status, while economic standards still range between the poorest homeless street beggar and the very opulent filthy rich - all of whom are, nevertheless, still legally equal.

The Igbo African society, for instance, the age grade system, considerably reflected the true picture of African democracy, equaling the task of public life and the socio-economic foundations of a peaceful society. It adopted a "highly decentralized autonomous forms, as well as direct and grassroots participation that accommodated every adult, who could partake simultaneously, unlike indirect or representative democracy" (Igwe, 2005, p.110).Democracy is one of the finest examples of a working human contrivance, whose basic objective is to promote human life and society. However, the greatest threat to it in the $21^{\text {st }}$ century remains its universal monopolization by moneyed men and consequent deprivation from the masses, who are the original owners, with all the attendant evil consequences. African interaction with the rest of the world has, no doubt, negatively affected her democracy, which is one of the negative outcomes of globalization.

Attempts at replicating conditions that incorporate a truly African democratic society, in modern times, in the form of socialism, as a result of globalization, failed partly because, these modern societies were mostly artificial creations, not natural law-governed points in the evolution of societies, and also because those modern societies pursued such democracies with a contradictory resource-destructive over-militarization of the society. The fundamental question, here, is: can any society fundamentally built upon the philosophy of material and social inequality actually believe itself to be democratic? The truth still remains that, today, people are still treated unequally and exploited and those benefiting from such unequal treatment and exploitation call it democracy. This is a clear pervasion of African democratic principles founded on the bases of equality and liberty. This pervasion is brought about by the bondage of globalization. What we have, today, rather, is what Friedrich Nietzsche calls "political nihilism" (Nietzsche, 1967), which is the devaluation of political values. Similarly, the situation in Africa, today, could be described as one of "political democratic nihilism," which is the devaluation of African Democratic values and the most cherished African ideals, brought about by the spirit of globalization. Consequently, African democratic values have been transformed from the one of communalism to that of individualism, which points to the emergence of the politics of subjectivity in Africa. The politics of subjectivity represents the highest manifestation of selfishness. It is founded on the doctrine of ontological solipsism-for-me-ness or only myself and the world. The politics of subjectivity recognizes the existence of only one's self and construes every other individual as non-existing. It designates the highest embodiment of self-centeredness. This ontological recognition of only the existence of one's self destroys the fabrics of African democracy, which is founded on the principle of communalism. The politics of subjectivity, as the recognition of the self, alone, as the only existing being, conceives every other individual, apart from one's self, as mere object over which dominion is to be exercised. Consequently, other individuals, apart from one's self, are construed not as an end in themselves, but only a means to an end. This violates Immanuel Kant's philosophical injunction of treating humans as end in themselves and not as a means to an end. It also violates the Kantian philosophical categorical imperative that urges one to act according to the maxim that one would wish one's action to become a universal law (Kant, 1991).

The politics of subjectivity is what is obtainable in today's African society. This manifests itself in 'godfatherism,' political assassination and the politics of calumny. The politics of god-fatherism, for example, represents the politics of selfishness. This type of politics favours only the interest of the select few - the political god-fathers, who are only interested in their selfish interest. For instance, what happened in one of the states in Nigeria, few years back, is a clear demonstration of the politics of subjectivity, which is the politics of selfishness, enthroned by the spirit of negative civilization, brought about by globalization. Few years back, in Anambra state, a governor of the state was abducted simply because, he refused to bring the allocation accruing to the state for sharing, by the cabals, in the state. This was a clear perversion of African democracy, founded on the doctrine of love, respect and care for one another. Similarly, political assassination, violence and electronic sophisticated rigging are no longer novel ideas. This is a clear pervasion of African democracy brought about by the spirit of globalization and negative western influences. What Africans require, therefore, is a strong will to power to resist the ugly and negative effects of globalization on our African democracy. This makes Nietzsche's principle of the will to power, which is a deconstructive and analytic tool highly imperative for African leaders. This will enable them constructively, critically and pragmatically scrutinize the effects of western values on our African democracy. 
Although Nietzsche is not a serious advocate of democracy, but his analytic and constructive principle of the will to power, if properly applied, can help African society develop a pragmatic, creative and critical way of thinking that will culminate into cultural, epistemic and political freedom. Just as Nietzsche's madman, in The Gay Science, believes that we have killed God, (Nietzsche, 2005, p.125), which is the source of value, African people have killed African democratic values by blindly keying into western values, as a result of globalization. What we need, therefore, is to resurrect, revamp and resuscitate these values. This can be accomplished through a revaluation of African values, driven by a strong will to power, to purge it of the ugly menace of globalization.

\section{The Will to Power and the Revaluation of African Values}

The theory of revaluation of value was developed by Friedrich Nietzsche, which is a deconstructive and interpretive principle. It is driven by the instrumentality of the will to power and was meant to deconstruct and reinterpret traditional western values, which Nietzsche believed to have stifled the development, creativity and culture of his people. His concern toward a revaluation of values was to work out a new theory of value, which would, at once, provide an interpretation and decisive reassessment of existing moral and evaluative schemes, and also fill the normative void, which their mere "devaluation," under critical scrutiny, would, otherwise, leave. He insists that his revaluation of values is mandated by "intellectual integrity" and "honesty," in philosophical thinking. Thus, his revaluation of values represents a deconstruction or dismantling of former values and traditional modes of valuation, as well as a development of a substantive alternative to them. His often-repeated contention is that "a genuine philosopher does not simply press into already existing formulas - some great data of former evaluations; and is not merely a critic - but establishes values, which, at least, in relation to previous values, will be new ones" (Nietzsche, 1966, p.135). According to him, "the new values must first be created and we will not be spared of this task!" "For us," he continues, "the philosopher must be a legislator" (Nietzsche, 1967, p.572). With the help of the dynamic and vibrant principle of the will to power, which is deeply rooted in the notion of becoming, Nietzsche intends to deconstruct the western traditional values of his time, which he believes have stifled their cultural creativity. He, therefore, intends to open up a new window of thinking for them: a new way of looking at these foreign values.

A clearer restatement of his programme of a "revaluation of values" would be a revaluation of those things, which traditionally or commonly, are supposed to be of greatest value. In proposing such a "revaluation," Nietzsche takes himself to be expressing a new demand: "that we cease to take received estimations of these things for granted, and that the value of these values, themselves, must be called into question" (Nietzsche, 1989, p.20).

Nietzsche holds that a number of questions should be raised with respect to existing values, in connection with the project of their revaluation, which facilitate it but do not, as such, constitute it. It could be recalled that he refers to the solution of the problem of value and the revaluation establishing the order of rank among values, as the future task of philosophers. This future task of philosophers, as Nietzsche pointed out, constitutes the present and urgent task of African leaders in connection with African cherished values, which have been greatly threatened by western values.

Nietzsche's theory of the revaluation of value, which is driven by his principle of the will to power, can help African society break away from the tyranny and hegemony of western values brought about by the ugly effects of globalization. It will constitute a foundation for the liberation of the African mind from the influence of negative western value, which our youths now see as the best and superior values. Rather, with the help of Nietzsche's theory of revaluation of values, driven by the instrumentality of the will to power, which is a deconstructive, analytic and critical tool, the inflows of western ideas and values will be critically, pragmatically and constructively assessed in terms of how they enhance African values, African way of life and African personality. This principle will also help our leaders come to the realization that western values, which are brought about by the spirit of globalization, are not better than our African values, for instance, the value of communalism as against western individualized way of life, respect for elders and so on.

On a similar note, African democratic ideals, which have been perverted, basterdized and mesmerized, will be critically and constructively re-assessed in terms of how they enhance African values and their congruency with African cultural milieu. Finally, as can be seen from the entire argument of the paper, Nietzsche's theory of the will to power, as a dynamic, critical, deconstructive and analytic tool, although has its shortfalls, but when properly and rightly applied, can help African society checkmate the ugly effects of globalization on African cultural values, while pragmatically harnessing its positive values.

\section{References}

Ajayi, S. I. (2003). "Globalization and equity in Sub-Saharan Africa: The Myth and the reality." In Kwame, Y. The impact of globalization on African culture. Odense, University of Southern Denmark, 1-10. Retrieved from http://www.csus.edu

Archibugi, D., \& Pietrobelli C. (2002). The globalization of technology and its implications for developing countries: Windows of opportunity or further burden. Technological Forecasting and Social Change, 70(2), 
$861-883$

Aristotle. (1991). Complete works of Aristotle. Ed. Jonathan, B. Verginia: Priceton University Press.

Bruno, Y. I. and Ojimba, C.A. (2018). Philosophy and education: The engines of national development. Journal of Philosophy, Culture and Religion,37-30-6.

Chukwuelobe, M.(2012). Eternal return and ilo uwa - Nietzsche and Igbo African thought: Implications for crosscultural philosophizing.Philosophy Today, 12(4) 39-48.

Crabbe, M., \& Corlett D. (2011). Technology, pornography and young people. Domestic Violence and Resource Centre Quarterly, 1-6.

Ekwuru, G. (1999). The pangs of an African culture in travail. Owerri: Totan Publishers Limited.

Fortich, I. (2010). Nietzsche's ubermensch: The notion of a higher aristocracy of the future. Civilizar10(5), 75-80.

Geller, S. (1995). The colonial era in Africa. Bloomington: Indiana University Press.

Heidegger, M. (1977). The question concerning technology and other essays. Trans. William, L. New York: Harper and Row Publishers.

Hofstede, G. (1980). Cultures consequences: International differences in work-related values. Berverly Hills: Sage Publications.

Igwe, O. (2005). Politics and globe dictionary. Aba: Eagle Publishers.

Jacob-Oluwagbemi.D. and Ojimba, A.C. (2017). Friedrich Nietzsche's will to power, globalization and democratic values in Africa. Ndunode: University of Calabar Journal of Humanities, 12(1), 76-91.

Kant, I.(1991). The metaphysics of morals.Ed. Guess, R. New York: Cambridge University Press.

Kwame, Y. (n.d). The impact of globalization on African culture. Odense, University of Southern Denmark, 1-10. Retrieved from http://www.csus.edu

Lingis, A. (1977). “The will to power." In Allison, B. The new Nietzsche. London: The MIT Press.

Maduagwu, O. M. (1999). Globalization and its challenges to national cultures and values: A perspective from Sub-Saharan Africa. In Oseni, T. A. Globalisation and value system. LUMINA, 22(2), 1-12. Retrieved from http://lumina.hnu.edu.ph

Nietzsche, F. (1966).Beyond good and evil: Prelude to a philosophy of the future. Trans. Walter Kaufmann. New York: Vintage Books.

Nietzsche, F. (1968). The will to power. Trans. Walter Kaufmann and R.J. Hollingdale. New York: Vintage Books.

Nietzsche, F. (1989). On the genealogy of morals. Trans. Walter Kaufmann and R.J. Hollingdale. New York: Vintage Books.

Nietzsche, F. (1996).Human, all too human: A book for free spirits. Trans. R.J. Hollingdale. United Kingdom: Cambridge University Press.

Nietzsche, F. (1999).The birth of tragedy. Ed. Raymond Geuss and Ronald Spieirs. New York: Cambridge University Press.

Nietzsche, F. (2001).The gay science. Ed. Bernard Williams. New York: Cambridge University Press.

Nietzsche, F. (2006).Thus spoke Zarathustra. Trans. Adrian Del Caro. Ed. Adrian Caro and Roberts B. Pippin. New York: Cambridge University Press.

Nsibambi, A. (2001). "The effects of globalization on the state in Africa: Harnessing the benefits and minimizing the costs." In Kwame, Y. The impact of globalization on African culture. Odense, University of Southern Denmark, 1-10. Retrieved from Retrieved from http://www.csus.edu

Obioha, U. P. (2010). Globalization and the future of African culture.Philosophical Papers and Reviews, 2(1), 18.

Odimegwu, I. (2006). "Globalization and the African Identity." In Oseni, T. A. Globalization and value system. LUMINA, 22(2), 1-12. Retrieved from http://lumina.hnu.edu.ph

Ojimba, C.A., Bruno, Y. I. and Haaga T. P. (2015). On the problem of language in African philosophy. Contemporary Journal of Art and Science, 1(2), 104-113.

Ojimba, C.A. (2013). Ethnicity and national integration in Nigeria: The historical role of colonialism. Contemporary Journal of Educational Research, 5(1), 15-33.

Ojimba, C.A. and Bruno Y. I. (2019). Friedrich Nietzsche's Superman and its Religious Implications. Journal of Philosophy, Culture and Religion.

Oseni, T. A. (n.d). Globalisation and value system. LUMINA, 22(2), 1-12. Retrieved from http://lumina.hnu.edu.ph Roubiczek, P. (1966). Existentialism for and against. London: Cambridge University Press.

Ugbam, C. U., Chukwu B., \& Ogbo A. (2014). The effects of globalization on African culture: The Nigerian perspective. IOSR Journal of Business and Management, 16(4), 62-71.

Bruno Yammeluan Ikuli is a Philosophy lecturer in Federal University Otuoke, Bayelsa State, Nigeria. He is the Coordinator, General Education Studies (GES). He became a Member, Researchers International Network in 2014. That same year (2014), he became a Member, Nigeria Philosophical Association (NPA). He holds a Ph.D. in Social and Political Philosophy from the University of Nigeria, Nsukka. 
Anthony Chimamkpam Ojimba is lecturer in the Department of Philosophy, University of Nigeria, Nsukka, Nigeria. He is the Nigerian South East Coordinator, Researchers International Network (RIN). He is also a member, Nigeria Philosophical Association (NPA). He holds a Ph.D in Metaphysics from the University of Nigeria, Nsukka. 